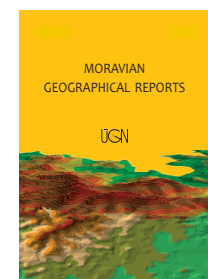

MORAVIAN GEOGRAPHICAL REPORTS

\title{
An integrated AHP and PROMETHEE approach to the evaluation of the attractiveness of European maritime areas for sailing tourism
}

\author{
Leszek BUTOWSKI a *
}

\begin{abstract}
As a subject of scientific investigation, evaluations of the attractiveness of tourist destinations have had a relatively long history, particularly among geographers and regional economists. Based on mathematical and psychological principles and using methods that combine the Analytical Hierarchy Process (AHP) and the Preference Ranking Organization Method for Enrichment Evaluation (PROMETHEE) approach, this research project constructs an evaluation structure used for the assessment of European coastal and offshore areas for sailing tourism. A case study with a three-level evaluation structure has been defined and tested. It contains: at the top of the hierarchy an overall objective defined as the attractiveness of the European coastal and offshore areas for sailing tourism; six criteria of evaluation (on the second level); and ten coastal areas (at the bottom level). This structure covers almost all the coasts around Europe, as they were the subjects of evaluation and comparison. The evaluation was carried out by a group of experts who made the assessment taking into account previously determined criteria with weights. The findings indicate that the AHP-PROMETHEE method may be a useful tool to evaluate the attractiveness of different destinations. It can be also used for practical purposes, particularly to determine strengths and weaknesses, as well as the competitive position, of given coastal areas in relation to others.
\end{abstract}

Keywords: AHP method; PROMETHEE method; evaluation; attractiveness of destinations for sailing tourism; European coastal and offshore areas

Article history: Received 10 November 2017; Accepted 18 May 2018; Published 30 June 2018

\section{Introduction}

The concept of the attractiveness of destinations (tourism attractiveness) is one of the most frequent issues studied in the theory of tourism and its adjacent disciplines in recent decades. Many authors have investigated this topic, resulting in a significant body of knowledge. They have focused on various aspects of attractiveness, with emphasis on the notion of tourism attraction as a foundation for the whole concept (see inter alia: Cohen, 1972; Cracolici and Nijkamp, 2009; Kim and Agrusa, 2005; Krešić, 2007; Kruczek, 2011; Leask, 2010; Lew, 1987; Omerzel and Mihalič, 2008; Pikkemaat, 2004; Ritchie and Crouch, 2005; Yoon and Uysal, 2005; Żemła, 2014).

This key concept of tourism attraction has usually been understood as those (tangible and intangible) attributes of destination, which, with their specific features, motivate tourists to visit a given area (Kreive and Prebeen, 2011). Additionally, apart from tourism attractions per se, factors such as transportation and accommodation (Cho, 2008;
Gołembski, 2002; Rogalewski, 1974), along with destination image (Anholt, 2010; Gartner, 1989; Kim and Perdue, 2011) play an important role in relation to the attractiveness of tourism areas. Such a delineation of tourism attractiveness can be referred to as the 'supply-driven' approach, but the concept of attractiveness of destination may also be analysed from a 'demand-driven' perspective (Formica and Uysal, 2006). Under such an approach, attractiveness is a function of the tourists' perception of the ability of the destination to satisfy their needs and deliver personal benefits (Mayo and Jarvis, 1980).

The evaluation of tourist attractiveness as a subject of scientific investigation has had a relatively long history, particularly among geographers and regional economists. The latter have rather dealt with the evaluation of tourism competitiveness and the potential of destinations, and they have proposed and applied many methods (also those developed in other disciplines) which have been used for these purposes. Historically, the most popular methods concerned the 'supply-

\footnotetext{
${ }^{\text {a }}$ Institute of Urban Geography and Tourism, Faculty of Geographical Sciences, University of Lodz, Lodz, Poland (*corresponding author: L. Butowski, e-mail: leszek.butowski@gmail.com)
} 
driven' approach and encompassed: grade and optimisation methods (since the 1970s - especially popular among Central and Eastern European geographers: Deja, 2001; Dubel, 2000; Husbands, 1983; Kożuchowski, 2005; Sołowiej, 1992; Ziółkowski, 2006), along with methods of multivariate comparative analysis and SWOT analysis (Zajadacz and Śmiałek, 2009). In recent decades, a set of multi-criteria decision- making tools have been intensively applied to the evaluation of tourist attractiveness. They take into account both the 'supply-driven' and 'demand driven' perspectives. Particular methods from the above-mentioned groups have been mainly used for the assessment of selected features of natural (Bartkowski, 1971; Deng, King and Bauer, 2002; Raymond and Brown, 2006; Sołowiej, 1992) and socio-cultural environments (Paprzycka, 2005), which are important for tourism development. The results of such assessments may constitute the basis for the valorisation of different areas as present or potential tourist destinations.

With regard to tourism in maritime and coastal environments, even at the beginning of the first decade of the $2000 \mathrm{~s}$, Hall (2001, p. 601) claimed that "marine and coastal tourism is one of the fastest growing areas within the world's largest industry. Yet despite increased awareness of the economic and environmental significance of marine and coastal tourism, it is only in recentyears that a substantialbody of research has emerged". Unfortunately, it seems that one cannot share the same opinion in relation to sailing tourism (as one of the forms of nautical tourism). Rather, it constitutes a minor subject of scientific investigation in the spectrum of nautical tourism's various issues (Lukovic, 2012; 2013). This is perhaps related to the fact that mainstream research has mainly dealt with the impact of tourism on coastal areas, as well as their adaptation to different tourists' and local societies' requirements (Balaguer et al., 2011; Charlier and De Meyer, 1992; Miossec, 1988; Qanir, 1989; Silveira and Santos, 2012; 2013; Worm, 1997). On the other hand, the seas and oceans themselves have constituted a relatively limited field of academic interest in tourism, mostly from the perspective of the marine environment, cruising tourism and the management of coastal waters areas (Papathanassis and Ross, 2015; Lück, 2007; 2008). Such a conclusion may also be derived from a content analysis of specialised journals, such as Ocean and Shorelines Management, Ocean and Coastal Management (Elsevier), the Journal of Coastal Research (Coastal Education and Research Foundation), Tourism in Marine Environments (Cognizant Communication Corporation), and Tourism Geographies (Routledge).

Coastal and offshore areas (as destinations for sailing tourism) have been rarely treated on a comparable level to other forms of maritime tourism. This is not fully understandable, since sea coasts have met the criteria with which tourist destinations can be distinguished and analysed for many decades. In recent years, among relatively infrequent publications (found mainly in the aforementioned international journals) where studies on maritime sailing tourism (carried out from different academic perspectives) have constituted the subject of interest, one can cite the following examples: Parrain's analysis of sailing routes and stopovers across the Atlantic (2011); a study of critical factors in the maritime yachting tourism experience (Mikulić, Krešić and Kožić, 2015); an estimation of the economic impacts of yachting in Greece by means of the tourism satellite account (Diakomihalis and Lagos, 2008); an analysis of recreational boaters' perceptions of scenic value in coastal waters off Rhode Island by Dalton and Thompson (2013); an analysis of incidents involving recreational boats in Spain
(Otamendi and González de Vegas, 2014); a study of the impacts of recreational boating on the marine environment of Cap de Creus (Mediterranean Sea) conducted by Lloret et al. (2008); a study of nautical frequentation and marina management in the Bay of La Rochelle (Marrou, 2011); and Retičre's (2002) analysis of recreational sailing in the Solent and the Bay of Quiberon.

As one can see, most of these publications have been concerned with rather fragmentary research, devoted to particular places and with relatively narrow topics. In turn, only a minority of works has dealt with more general issues connected with problems which may be encountered in many different coastal and offshore destinations. Among such publications, one can note the following: Lee's (2001) analysis of the determinants of recreational boater expenditures on trips; Oram's (2007) and Marušić et al.'s (2008) studies on the positive and negative impacts of yachting tourism; a study devoted to the genetic, structural and functional aspects of maritime tourism space, published by Butowski (2014); and a simulation of yacht movements in enclosed bays by means of computer modelling (Genç, 2015). The environmental impacts of yachting tourism are among the most controversial. Certain authors argue that small and recreational vessels exert a significant pressure on the delicate ecological balance of maritime habitats (Davenport and Davenport, 2006; 2008, and Salmona and Verardi, 2001). On the other hand, it is also acknowledged that such vessels do not have a significant influence on the environment, especially when compared to the environmental impacts of large cruise ships (Mikulić, Krešić and Kožić, 2015, p. 33).

In addition, coastal and offshore tourist destinations in relation to sailing tourism have rarely been the subject of comparative studies. Paradoxically, they have constituted the main topic (but from a different perspective) of many publications issued for practical reasons. They primarily comprise pilot books and guides for sailors (e.g. for European waters: Atlantic Spain and Portugal (2006); Brandon and Marchment (2007); Buchanan (2009); Buttres and Du Port (2009); Cornell (2008); Heath (2006); Heikell (1998; 2006; 2007); Lawrence (2002); Navin (2003; 2004; 2006); Nickel and Harries (2009); South and West Coasts of Ireland (2006); Thompson and Thompson (2008); and the global publication in 2004 of Ocean Passages for the World). These are obviously not academic publications, but they can constitute a relevant source of information that may be used for the needs of scientific works, especially those which concern comparative studies among various maritime areas.

Taking into consideration the above-mentioned background factors, this study uses assessment procedures based on mathematical and psychological principles (combined AHP and PROMETHEE approaches: see below for definitions) to construct an evaluation platform for European coastal and offshore areas for sailing tourism. The aim of this research project is to contribute to the increased knowledge of European maritime areas as destinations for sailing tourism, as well as to the improvement of the methodological bases in studies of the evaluation of the attractiveness of coastal and offshore destinations.

\section{The AHP and PROMETHEE methods as multi- criteria decision-making tools}

The Analytical Hierarchy Process (AHP) method is a classical multi-criteria decision-making tool developed by the American mathematician T. L. Saaty in the 1970s, 
and it has been extensively studied and refined since then (1980, 1982, 1987, 1995 and 2008). It is a structured technique for organising and analysing complex problems based on mathematics and psychology. The method itself is based on a familiar way of thinking: instead of trying to define what is good and what is bad, it is usually much easier to compare one variant of some phenomenon or process to another.

In the AHP method, all factors affecting the decisionmaking process are structured into a tree hierarchy and assigned weights. It belongs to the set of variations on multi-attribute utility theory (MAUT), where the criteria are completely aggregated into a single utility function that takes the preferences of the decision makers into account (De Brucker, Verbeke and Macharis, 2004). The core of the AHP method is weighting criteria and indicators with pairwise comparisons. It has received increasing attention in the associated literatures and has been used to address decision making and evaluations in a number of interdisciplinary contexts.

The standard AHP method is based on three principles:

1. construction of a hierarchy;

2. priority setting; and

3. logical consistency (Turcksin, Bernardini and Macharis, 2011, p. 955).

First, the hierarchy is used to break down the complex problem into its constituent elements. A hierarchy has at least three levels: the overall objective at the highest level; the (sub-) objectives (criteria) at an intermediate level; and the considered alternatives at the bottom level (Macharis et al., 2004; Dagdeviren, 2008). Secondly, the relative priorities of each element in the hierarchy are determined by comparing all the elements of the lower level against the criteria, with which a causal relationship is presumed to exist. The multiple pair-wise comparisons are based on a standardised comparison scale of 9 levels, where $1=$ equal importance, $3=$ moderate importance, $5=$ higher importance, $7=$ much higher importance, and $9=$ complete dominance; the ratings of $2,4,6$, and 8 are intermediate values; and $1 / 2,1 / 3,3 / 4, \ldots 1 / 9$ are reciprocals. The consistency of decision makers, as well as the hierarchy, can be evaluated by means of the consistency ratio (Wang and Yang, 2007). The whole procedure is explained in detail in Saaty (1987).

The Preference Ranking Organization METHod for Enrichment Evaluation (PROMETHEE), proposed by Brans, Mareschal and Vincke (1984) and further developed by Brans and Vincke (1985), as well as by Goumans and Lygerou (2000), is (similar to the AHP method) a set of multicriteria decision aid methods. They can also be classified as outranking methods, which are based on the principle of pair-wise comparison of the actions. The term 'action' is used in the original description of the PROMETHEE method. It corresponds to the term 'alternative' in the AHP method. The European maritime areas, which are the subjects of research in this study, played the role of actions (using the original terminology of the PROMETHEE method)

The general aim of all multi-criteria decision-aid methods is to point out an action (alternative) optimising all criteria, which can be maximised and minimised. In the PROMETHEE group methods, one uses information concerning the level of preference of a given action in relation to the remaining actions, as well as information on the level at which the remaining actions are more preferred in relation to a given action. The research process is carried out in five stages:
1. the choice of a type of function of preference for each pair of actions (there are six functions of preference which can be chosen, depending on the types of criteria);

2. the determination of individual indexes of preference for all pairs of actions in each criterion;

3. the determination of multi-criteria indexes of preferences for all pairs of actions;

4. the determination of flows of domination for each action as well as profiles of alternatives; and

5. the determination of rankings of actions on the basis of domination flows (Cabała and Onderka, 2015).

\section{Multi-criteria methods used in tourism (and nautical tourism) research}

The evaluation of the tourism attractiveness of destinations is a strongly multi-criteria assessment process where various criteria are often subjective, somewhat abstract or unquantifiable (Shou et al., 2015). Additionally, these criteria should be analysed from both 'supply driven' and 'demand driven' perspectives. Therefore it is appropriate to apply specialised multi-criteria decision-making tools to this task, as they deal with tangible and intangible factors which can influence the assessment of the tourism attractiveness of destinations. Those tools (using mathematical algorithms) allow the transformation of subjective opinions of experts into more objective final results, including evaluations or rankings of compared areas. The usefulness of such tools also relies on the fact that they are supported by software applications, which help to conduct the research and interpret the obtained outputs.

Among frequent instances of applications from around the world, one can distinguish several examples: the ranking of tourist destinations with multi-criteria decisionmaking methods in Bosnia and Herzegovina, as presented by Göksu and Kaya (2014); a combined SWOT - AHP approach applied by Joe and Kim (as cited in Göksu and Kaya, 2014, 92) to develop a strategic plan for a tourist destination in Chuncheona (South Korea); a tourist attractions' preference evaluation using a Bayesian network and the AHP method proposed by Papić-Blagojević, Gajić and Djokic (2012); the tourist attractiveness of the Tatra National Park (Poland) measured using the PROMETHEE and Hellwig's method (Muszyńska-Kurnik, 2010); and the evaluation of tourist potential in Romania carried out by means of Principal Components Analysis and Hierarchical Ascendant Classification, (Iațu and Bulai, 2010). The list can be completed by other examples of the application of multi-criteria methods in tourism research from the Spanish language literature, such as Mondéjar-Jiménez et al., (2010); Blancas, Guerrero and Lozano (2009); Brandis et al. (1998); Franco et al. (2009); Montis and Nijkamp (2006); Pérez et al. (2008); and Rozman et al. (2009).

The proper AHP and PROMETHEE approaches are probably the ones most popular among many multi-criteria techniques applied in tourism research. Moutinho, Rita and Curry (1996) examined the application of the AHP approach in a tourism context (Crouch, 2007; Papić-Blagojević, Gajić and Djokić, 2012, p. 10). Due to its advantages, the AHP method has been mainly employed in tourism studies addressing selection and/or evaluation issues, such as: natural attractions evaluation (Deng, King and Bauer, 2002); convention site selection (Chen, 2006; Filipović, 2007); hotel location choice (Chou, Hsu and Chen, 2008); online 
personalised attraction recommendation system (Huang and Bian, 2009); and tourism promotional effectiveness (Lai and Vinch, 2013). Using the case of Taiwan, Hsu, Tsai and $\mathrm{Wu}$ (2009) analysed preferences for tourists' choice of destination. Nekooee, Karami and Fakhari (2011) assessed the prioritisation of urban tourist attractions in Iran. And finally, Zhou et al. (2015) used the hybrid analytic hierarchy process (AHP) to evaluate resource-based destination competitiveness in West Virginia.

The PROMETHEE method (often in conjunction with its GAIA graphic plane - prepared for the visualisation of results) has also been used frequently in tourism research. In recent years, a number of works dealing with different aspects of tourism using this approach have been published. Among others, Ishizaka, Nemery and Lidouh (2013) carried out a location selection analysis for choosing a suitable borough in the region of Greater London to construct a large casino. Akkaya and Uzar (2013) and Uygurtürk and Korkmaz (2015) evaluated travel agencies operating in Turkey. And finally, Ranjan, Chatterjee and Chakraborty (2016) tried to quantify the tourism potential of Indian states.

The AHP and the PROMETHEE (and other multi-criteria) methods and tools were also applied in research connected with nautical tourism, but to a relatively limited extent. Over the last decade, among the few works which touch on these topics, one can point out the evaluation of natural and cultural attractions for sailing tourism by means of the AHP tool (Adamczyk and Nowacki, 2014), or the selection of locations for nautical tourism ports in the Northern Adriatic using the PROMETHEE approach, as proposed by Kovačič (2010).

\section{Methodological scheme of the research}

This research project on the evaluation of European coastal and offshore areas for sailing tourism was carried out taking into account both 'supply-driven' and 'demanddriven' approaches of tourism attractiveness. It encompassed four main stages:

1. the determination of:

- the overall objective of research,

- the criteria of evaluation, and

- the selection of the areas (supply perspective) for further comparison;

2. setting-up a three-level hierarchical decision tree to clarify the process;

3. the weighting the criteria (demand perspective, using the AHP methodology); and

4. the evaluation and ranking of chosen areas (demand perspective, using the PROMETHEE methodology).

The overall objective is defined as determining the attractiveness of European coastal and offshore areas (destinations) for tourism. For the purpose of this research project, six criteria (Tab. 1) and ten areas (Tab. 2) were determined. In order to appropriately weight the criteria and

\begin{tabular}{|c|c|}
\hline Criteria & Sub-criteria \\
\hline Safety and comfort of navigation (S\&C) & $\begin{array}{l}\text { ports, marinas and natural shelters } \\
\text { search and rescue systems (SAR) } \\
\text { navigational and meteorological warnings } \\
\text { maps (traditional and electronic), pilot books and guides for sailors } \\
\text { weather conditions } \\
\text { the intensity and organisation of navigation (e.g. occurrence of separation zones), } \\
\text { buoyage and lights }\end{array}$ \\
\hline Nautical conditions (NC) & $\begin{array}{l}\text { the length of sailing season for recreational crafts } \\
\text { nautical attractiveness and the level of nautical difficulty of a given area } \\
\text { (meteorological and hydrological conditions: tides and currents, force and direction of } \\
\text { prevailing winds, the height of waves, depths and shoals, etc.) }\end{array}$ \\
\hline Tourist attractiveness of destinations (TA) & $\begin{array}{l}\text { climate and weather conditions } \\
\text { natural attractions (landscape, beaches, clear water, nature, natural parks and } \\
\text { reserves, etc.) } \\
\text { cultural attractions (towns, museums, exhibitions, monuments, architecture, people, } \\
\text { local culture, events, etc.) } \\
\text { degradation of the natural and cultural environments }\end{array}$ \\
\hline Formalities (F) & $\begin{array}{l}\text { required formal procedures (concerning the boat and crew members) } \\
\text { the occurrence of water areas which are inaccessible for recreational sailing }\end{array}$ \\
\hline Commercial offer for sailors (CO) & $\begin{array}{l}\text { the level of prices } \\
\text { the prices/quality relation } \\
\text { the diversity of offer } \\
\text { the cost of transportation }\end{array}$ \\
\hline Accessibility and location of destinations (A\&L) & $\begin{array}{l}\text { the duration of travel to a destination } \\
\text { the accessibility of different means of transport (plane, road, ferry) } \\
\text { the location of destination (distance from main source areas) } \\
\text { the location of destination in relation to other areas (the synergy or isolation effect) }\end{array}$ \\
\hline
\end{tabular}

Tab. 1: Criteria (and sub-criteria) applied in the evaluation process

Source: author's conceptualisation 


\begin{tabular}{|c|c|}
\hline Selected maritime area & Covered areas \\
\hline The Baltic Sea (BS) & $\begin{array}{l}\text { Danish straits, the Kattegat; coastal and island areas: Danish, Swedish, Ĺland } \\
\text { Islands, Finnish, Russian, Estonian, Latvian, Lithuanian, Polish, German }\end{array}$ \\
\hline The North Sea (NS) & $\begin{array}{l}\text { the Skagerrak, coastal and island areas of eastern Britain, Shetland, Orkney, } \\
\text { southern and western Norway (south of Ĺlesund), western and northern } \\
\text { Denmark, Germany and the Netherlands }\end{array}$ \\
\hline The Norwegian Sea and the Atlantic Ocean (Nw.S) & coastal and islands areas Norway (north of Ålesund), Faroe Islands, Iceland \\
\hline The Irish Sea, the Celtic Sea, the Atlantic Ocean (ISA); & coastal and island areas of western Britain, the Hebrides, waters around Ireland \\
\hline The English Channel, Bay of Biscay, Atlantic (ECBA) & $\begin{array}{l}\text { southern coast of Britain, Channel Islands, the Bay of Biscay, western coast of } \\
\text { the Iberian Peninsula }\end{array}$ \\
\hline Atlantic Islands (AIs) & the Canaries, Madeira, the Azores \\
\hline Western Mediterranean (WM) & $\begin{array}{l}\text { the Tyrrhenian Sea; coastal and island areas of Spain, the Balearic Islands, } \\
\text { France, Corsica, Sardinia, Sicily }\end{array}$ \\
\hline Central Mediterranean $(\mathrm{CM})$ & $\begin{array}{l}\text { the Adriatic Sea, the Ionian Sea; coastal and island areas of Italy, Slovenia, } \\
\text { Croatia, Montenegro, Albania, Greece, Malta }\end{array}$ \\
\hline Eastern Mediterranean (EM) & $\begin{array}{l}\text { the Aegean Sea, the Sea of Marmara (EM); coastal and island areas of Greece, } \\
\text { Turkey, Cyprus }\end{array}$ \\
\hline The Black Sea (Bl.S) & the coastal areas of Bulgaria, Romania, Ukraine, Russian Federation, Georgia, Turkey \\
\hline
\end{tabular}

Tab. 2: The geographical scope of chosen European coastal and offshore areas

Source: author's conceptualisation

then to use them for the evaluation of tourist attractiveness, a set of sub-criteria for each criterion was defined. In such a way, each criterion was qualitatively determined by the set of sub-criteria (in the full AHP procedure, the sub-criteria could constitute a fourth level of the hierarchy: this was not applied in this research).

The European coastal and offshore areas (as 'alternatives' in the AHP methods, and 'actions' in the PROMETHEE terminology) have been selected such that the coverage of all coasts, as well as coastal and offshore waters around Europe, are included as accessible for recreational crafts. The chosen areas should be (as much as possible) comparable in terms of their geographical extent and socioeconomic potential. Many pilot books and sailing guides (some of them listed in section 1 of this paper), as well as the author's 30 years personal experience in such sailing, were taken into consideration to meet these requirements (Fig. 1, Tab. 2).
Based on the AHP methodology and using the abovementioned assumptions, a three-level hierarchical decision tree was constructed. It allowed for the partition of the complex problem of the attractiveness of tourist destinations into particular factors presented at the $2^{\text {nd }}$ and $3^{\text {rd }}$ levels of the decision tree (Fig. 2).

The criteria selected for the evaluation of attractiveness of European coastal and offshore areas for sailing tourism were weighted using the AHP methodology. They were pairwise comparisons carried out by a group of 24 sailors with little, average (e.g. qualified crew members) and extensive (e.g. skippers and sailing tourism organisers) experience in maritime sailing. Such a structure for this group of sailors allowed the researcher to take into account the different significances of particular criteria for less-experienced, medium-experienced and experienced sailors. The final weight assigned to each criterion constituted an average of all partial weights (Tab. 3).

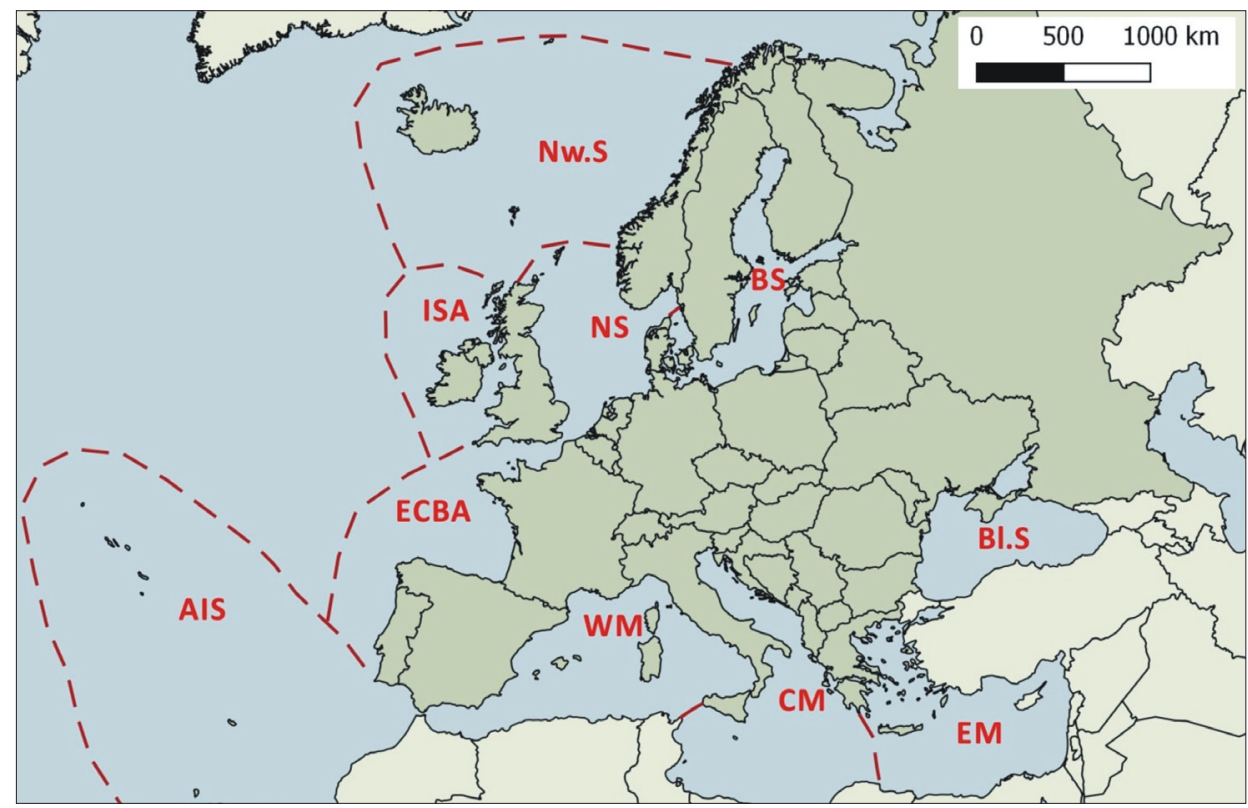

Fig. 1: European coastal and offshore areas as alternatives in the evaluation process

Source: author's elaboration 


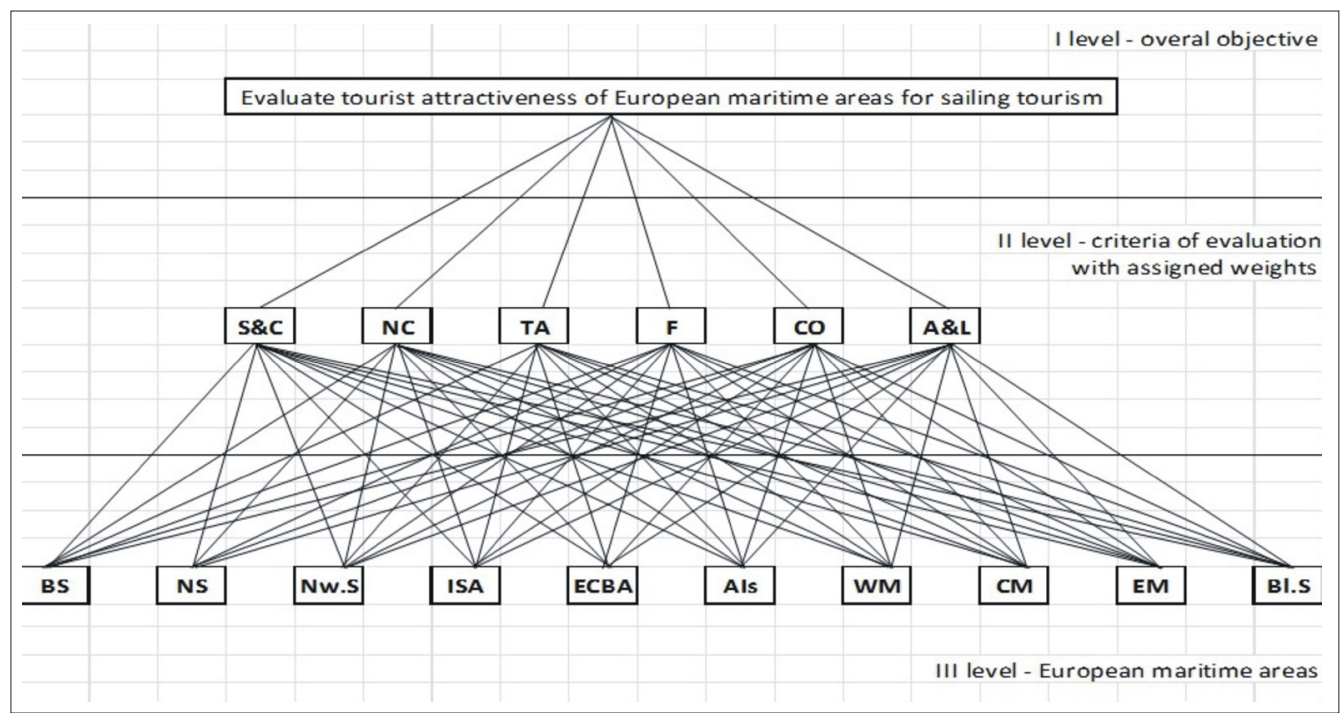

Fig. 2: The attractiveness of European coastal and offshore areas for sailing tourism: The hierarchical tree and pair-wise comparisons

Source: author's conceptualisation

(Notes: Level 11: S\&C-Safety and Comfort of navigation; NC-Nautical Conditions; TA - Tourist Attractiveness of destinations; F-Formalities; CO - Commercial Offer; A\&L - Accessibility and Location of destinations; Level 111: BS - The Baltic Sea; NS - The North Sea; Nw.S - The Norwegian Sea; ISA - The Irish Sea and Atlantic; ECBA The English Channel, Bay of Biscay, Atlantic; AIs - Atlantic Islands; WM - Western Mediterranean; CM - Central Mediterranean; EM - Eastern Mediterranean; Bl.S - The Black Sea)

\begin{tabular}{|c|c|c|c|c|c|c|c|c|}
\hline \multirow{2}{*}{ Group of sailors } & \multirow{2}{*}{$\begin{array}{c}\text { Number of } \\
\text { participants }\end{array}$} & \multicolumn{6}{|c|}{ Criteria } & \multirow{2}{*}{$\begin{array}{c}\text { Ratio of } \\
\text { consistency }\end{array}$} \\
\hline & & $\mathrm{S} \& \mathrm{C}$ & $\mathrm{NC}$ & $\mathrm{TA}$ & $\mathrm{F}$ & $\mathrm{CO}$ & (A\&L) & \\
\hline Experienced sailors & 7 & 0.33 & 0.22 & 0.09 & 0.22 & 0.07 & 0.07 & $6.7 \%$ \\
\hline Medium-experienced sailors & 7 & 0.29 & 0.19 & 0.17 & 0.07 & 0.13 & 0.14 & $7.5 \%$ \\
\hline Less-experienced sailors & 10 & 0.44 & 0.14 & 0.23 & 0.04 & 0.08 & 0.07 & $6.4 \%$ \\
\hline Total & 24 & 0.35 & 0.18 & 0.17 & 0.10 & 0.10 & 0.10 & $6.9 \%$ \\
\hline
\end{tabular}

Tab. 3: Weights assigned to the criteria of evaluation (Notes: *For the description of specific criteria see Tab. 1; **The Ratio of consistency should not exceed 10\%)

Source: author's survey

In the next stage, according to PROMETHEE principles, a 'usual' function was chosen as a function of preference applied particularly in qualitative assessments. Then, the ten selected European coastal and offshore areas were evaluated by 10 'experts' (this time only by experienced skippers and sailing tourism organisers, and all of them must have had knowledge of all areas in question) using a 5-level qualitative scale ( 1 - very bad; 2 - bad; 3 - average; 4 - good; 5 - very good) against to each criterion. The interviews were conducted between April and June, 2016.

The idea of joining both the AHP and PROMETHEE methods together resulted from the fact that, in the PROMETHEE procedure, weights assigned for each criterion are determined in a quite subjective way only by a researcher. This can cause the situation that the obtained results will be encumbered with subjectivity. To avoid this danger, in the first step of the whole procedure, the AHP technique was applied. Based on its principles, the weights were determined by pair-wise comparison of six criteria carried out by sailors from various groups. This has reduced the subjectivity of the researcher, replacing it with more objective opinions of many groups of sailors. In such a way the relative values of weights for each criterion were computed. The remaining part of the research was carried out according to the PROMETHEE methodology.

\section{Results}

According to the applied procedure, the criteria selected for the evaluation of the attractiveness of the chosen European coastal and offshore areas were weighted using the AHP methodology (in practice all calculations were made using the AHP calculator: for academic purposes, it is accessible at: emic/ahp_calc.php). The values of weights assigned to each criterion are presented in Table 3. Additionally, apart from the final weights, certain differences which occurred among experienced, medium-experienced and less-experienced sailors have also been shown. They point out the different importance of particular criteria among these sub-groups of sailors.

The next step of the analysis was to evaluate (and rank) the European coastal and offshore areas by experts using the PROMETHEE method. The data have been processed by means of the PROMETHEE-GAIA plane - a special software for computing and the graphical presentation of the results for this purpose a version for all non-profit academic research and teaching was used (http://www.promethee-gaia. net/software.html).

The complete ranking of the evaluated areas is presented in Table 4. It also contains the values of the preference flows which are computed to consolidate the results of the pair-wise comparisons of the areas and to rank them from 
the most preferred to the least preferred. There are three types of preference flows (PROMETHEE methods. Visual PROMETHEE 1.4 Manual (2014, pp. 149-150):

1. Phi $+(\emptyset+)$ positive (leaving) flow:

$$
\emptyset^{+}(a)=\frac{1}{n-1} \sum_{b \neq a} \pi(b, a)
$$

where $a$ and $b$ are compared areas; it measures how much given area $a$ is preferred to the other $n-1$ ones. It is a global measurement of the strengths of area $a$. The larger $\emptyset+(a)$ the more preferred area;

2. Phi- (Ø-) negative (entering) flow:

$$
\emptyset^{-}(a)=\frac{1}{n-1} \sum_{b \neq a} \pi(b, a)
$$

it measures how much the other $n-1$ areas are preferred to area $a$. It is a global measurement of the weaknesses of area $a$. The smaller $\emptyset-(a)$ the more preferred area;

3. Phi $(\varnothing)$ net flow:

$$
\emptyset(a)=\emptyset^{+}(a)-\emptyset^{-}(a)
$$

the net preference flow shows the balance between the positive and negative preference flows. It thus takes into account and aggregates both the strengths and the weaknesses of the area into a single score. $\emptyset(a)$ can be positive or negative. The larger $\emptyset(a)$ the more preferred area.

In the complete ranking all the areas are compared (it includes no incomparabilities even when comparison is difficult). The resulting ranking can thus be more disputable, especially in the presence of strongly conflicting criteria. The ranking is based on the net preference flow. It combines the two other preference flows in a single summary score. So area $a$ is preferred to area $b$ if and only if it is preferred to $b$ according to the net preference flow:

$$
a P b \text { if and only if } \varnothing(a)>\varnothing(b)
$$

The obtained results clearly show that the highest ranks (positive net flows) are occupied by the southernmost European coasts with two exceptions - the Baltic and the Black Sea area, which can be caused by the fact that all maritime areas were assessed from the perspective of Polish participants. All northernmost seas characterised by negative net flows. The Black Sea was assessed as the least attractive in comparison with other areas by a large degree.
The PROMETHEE-GAIA tool also allows the presentation of a disaggregated view of the complete ranking (Fig. 3). For each evaluated area a bar is drawn with as many bands as the number of criteria. Each band corresponds to the contribution of the criterion to the Phi net flow score of the area taking into account the weight of the criterion. This way the sum of the positive bands minus the sum of the negative ones is equal to the Phi net flow score of the area.

On the graph (Fig. 3) it is clearly shown that in the Central Mediterranean area almost all criteria positively contributed to the net flow score. In contrast the Black Sea characterised by negative contribution of all criteria to the final net flow score.

The PROMETHEE-GAIA software also makes possible the computing of the partial ranking. This means that all the evaluated areas are not necessarily compared (because of conflicting criteria) and that the ranking can include incomparabilities. The partial ranking is based on the preference flows. As the two preference flows consolidate the pairwise comparisons of the areas according to opposite points of view, they usually induce two different rankings on the set of areas. The partial ranking is the intersection of these two rankings. So area $a$ is preferred to area $b$ in the partial ranking if and only if it is preferred to $b$ according to both preference flows:

$$
a P b \text { if and only if } \emptyset^{+}(a) \geq \emptyset^{+}(b) \text { and } \emptyset^{-}(a) \leq \emptyset^{-}(b)
$$

Whenever the two preference flows give opposite rankings of the areas, the areas become incomparable.

In Figure 4 the partial ranking was presented in a way such that all areas are represented by nodes and arrows are drawn to indicate preferences. Incomparabilities are thus very easy to detect. Taking into account the condition that area $a$ is preferred to area $b$ if and only if it is preferred to $\mathrm{b}$ according to both preference flows, one can see that not all areas are comparable. This feature concerns the following areas: Western Mediterranean - WM (Phi+: 0.34, Phi-: 0.10); the Baltic Sea - BS (Phi+: 0.36, Phi-: 0.13); Eastern Mediterranean - EM (Phi+: 0.41, Phi-: 0.22); The North Sea - NS (Phi+: 0.09, Phi-: 0.30); and The Norwegian Sea - Nw.S (Phit: 0.13, Phi-: 0.33).

Apart from the complete and partial rankings, a more detailed qualitative analysis was conducted. It was carried out by means of the special GAIA plane tool (Fig. 5) which contains three types of information:

\begin{tabular}{clccc}
\hline Rank & \multicolumn{1}{c}{ Maritime areas } & Phi & Phi+ & Phi- \\
\hline 1 & Central Mediterranean & 0.6211 & 0.6767 & 0.0556 \\
2 & West Mediterranean & 0.2378 & 0.3367 & 0.0989 \\
3 & The Baltic Sea & 0.2267 & 0.3589 & 0.1322 \\
4 & East Mediterranean & 0.1933 & 0.4100 & 0.2167 \\
5 & Atlantic Islands & 0.0600 & 0.2700 & 0.2100 \\
6 & The Irish Sea \& Atlantic & -0.1122 & 0.1422 & 0.2544 \\
6 & English Chanel \& Biscay & -0.1122 & 0.1422 & 0.2544 \\
8 & The North Sea & -0.2011 & 0.0978 & 0.2989 \\
8 & The Norwegian Sea & -0.2011 & 0.1311 & 0.3322 \\
10 & The Black Sea & -0.7122 & 0.0000 & 0.7122 \\
\hline
\end{tabular}

Tab. 4: The complete ranking of the European coastal and offshore areas Source: author's calculations 
1. actions (maritime areas) - represented by small squares;

2. criteria - represented by axes; and

3. the weighting of the criteria and the complete ranking represented by the decision axis (a thicker line).

Using this tool, one can represent in a very synthetic form interrelations which occur within and between particular areas and criteria. One should remember, however, that applying the GAIA plane tool in order to obtain such different types of comprehensive information in a relatively simple pattern, we have to accept the loss of accuracy and quality of information.

The positions of all areas represented graphically in Figure 5 as squares are related to their evaluations on the set of criteria in such a way that areas with similar profiles are closer to each other. In this case, one can distinguish three groups of areas with similar profiles:

1. the Norwegian Sea (Nw.S), the English Channel, Bay of Biscay and Atlantic area (ECBA), the Irish Sea with coastal Atlantic - ISA (ECBA and ISA overlap each other and thus they occupy the same location in this diagram), as well as the North Sea (NS);

2. the Western Mediterranean (WM) area and the Baltic Sea (BS);

3. Atlantic Islands (AIs) and the Eastern (EM) and Central Mediterranean (CM). The Black Sea (Bl.S) area is characterised by a completely different profile.

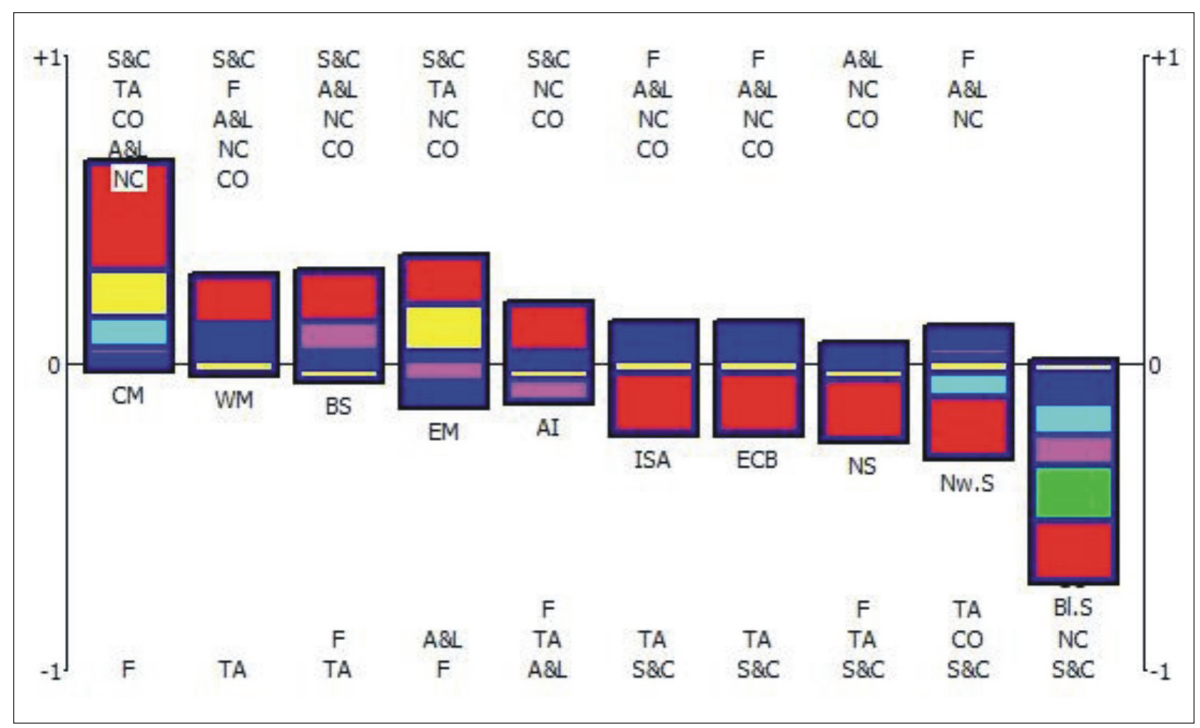

Fig. 3: The complete ranking of the European coastal and offshore areas using the PROMETHEE rainbow tool (Note: S\&C - Safety and Comfort of Navigation [red], NC - Nautical Conditions [lime], TA - Tourist Attractiveness of destinations [yellow], F-Formalities [blue], CO - Commercial Offer [aqua], A\&L - Accessibility and Location of destinations [violet]; BS - The Baltic Sea, NS - The North Sea, Nw.S - The Norwegian Sea, ISA - The Irish Sea and Atlantic, ECB - The English Channel, Bay of Biscay, Atlantic, AIs - Atlantic Islands, WM - Western Mediterranean, $C M$ - Central Mediterranean, EM - Eastern Mediterranean, Bl.S - The Black Sea)

Source: author's elaboration

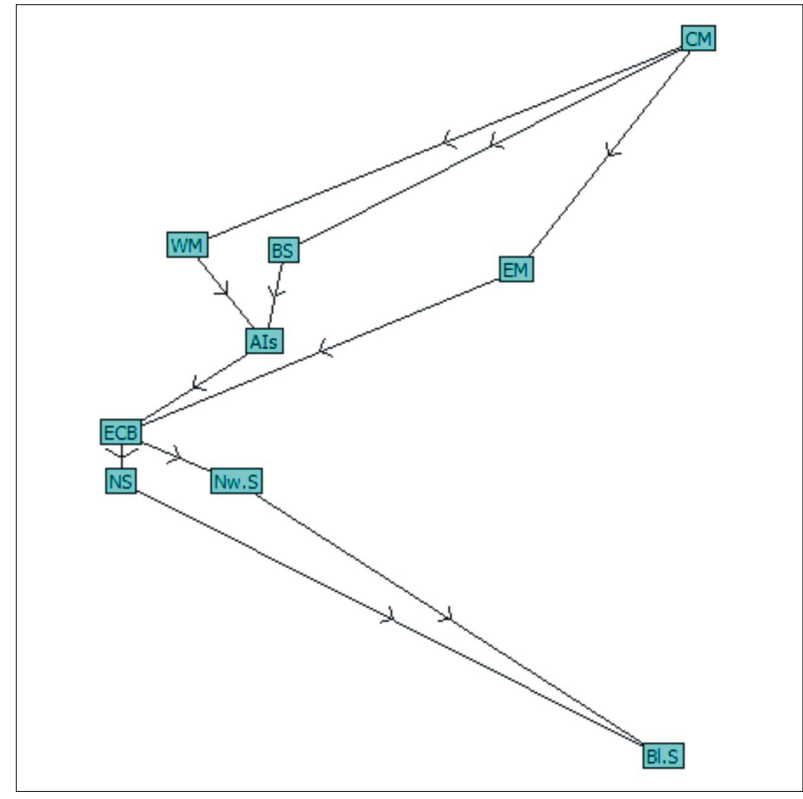

Fig. 4: The partial ranking of the European coastal and offshore areas (Note: for legend, see Fig. 3)

Source: author's elaboration

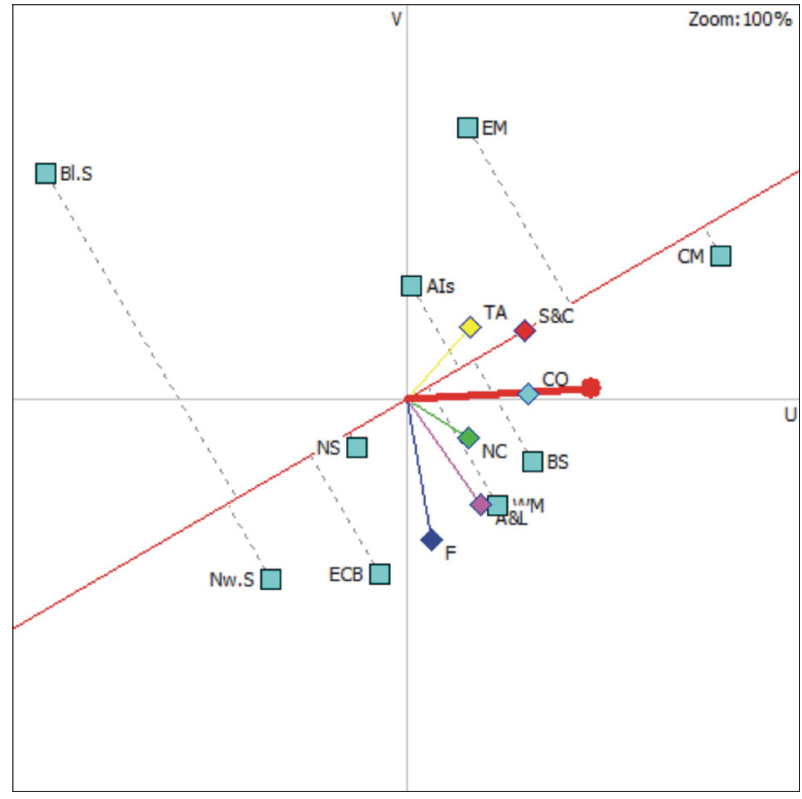

Fig. 5: The GAIA plane as a tool for qualitative evaluation of the European maritime areas (Note: for legend, see Fig. 3). Source: author's elaboration 
To better understand the differences between distinguished groups of areas one may analyse the criteria. Each criterion is represented by an axis drawn from the centre of the plane. The orientation of these axes indicates how closely the criteria are related to each other (criteria expressing similar preferences have axes that are close to each other; conflicting criteria have axes that are pointing in opposite directions). Based on this assumption, one can state that all six criteria (chosen for the evaluation in this project) are not very conflicting, but they are not very similar either, wherein can be found the relatively most conflicting criteria, Formalities (F) in relation to Tourist Attractiveness (TA), which are placed in two extreme positions.

The relative positions of areas and criteria axes in the diagram are also interesting to analyse. They indicate which is the best area in relation to a given criterion. In Fig. 5, one can observe the general ranking of areas in terms of safety and comfort of navigation (S\&C). It is shown by the orthogonal projection of all areas on the direction of the axis S\&C. The highest positions are occupied by the Central and Eastern Mediterranean areas, while the lowest ranks are assigned to the Norwegian and Black Seas. In the same way, one may rank each area against each separate criterion.

Finally, the decision axis (the thickest line in Fig. 5) represents the weights of the criteria. Its orientation indicates which criteria are in agreement with the PROMETHEE rankings and which are not. In Figure 5 one may note that such criteria as Commercial Offer (CO), Nautical Conditions (NC), Safety and Comfort of Navigation (S\&C), as well as Tourist Attractiveness (TA), were mostly taken into account in the overall rankings.

The results of this type of research can also be used for more practical purposes: not only do they determine the competitive position of a given maritime area, but they also point out its strengths and weaknesses in relation to others. This can be particularly interesting and helpful for smaller areas, which compete with each other in terms of different criteria. An example of such an analysis are relative rankings of the areas in relation to particular criteria (Tab. 5). The results show the competitive advantage of particular areas in terms of particular criteria.
Another type of information which can be interesting for practical purposes is the relative assessment of a given area in terms of particular criteria. As an example, one can represent the evaluations of the Central Mediterranean area (the 1st position in the complete ranking) and the Black Sea (the last position in the complete ranking) - in a graphical form see Figures 6 and 7.

Analysing Figure 6, one can see (much more clearly than in the synthetic Fig. 4) that the Central Mediterranean area is characterised by a positive net flow for all criteria except Formalities. Moreover, one may notice that the relative position of this area (in relation to other areas) is very strong in terms of safety and comfort of navigation, commercial offer and tourist attractiveness. Only in terms of formalities does this area show a minimal negative flow.

On the other hand, the area of the Black Sea (Fig. 7) is characterised by negative flows in all criteria. A detailed analysis of these types of information can be helpful for decision makers in showing them in which fields their areas are strong or weak (in relation to potential competitors).

\section{Conclusions and implications}

Multi-criteria decision-making methods started to develop in the 1970s in an intensive fashion. They were mainly directed towards the support of decision-making processes and constituted the output of researchers in management science (although many of them were elaborated by mathematicians). Due to their usefulness, popularity and low cost, they were often adopted by other disciplines in various fields of study. Tourism, because of its complexity and heterogeneity, was one of these domains where frequent multi-criteria tools appeared to be rather attractive. As mentioned in section 3 , they were mostly applied to different types of tourism evaluation research. Unfortunately, the use of multi-criteria methods of assessment in nautical tourism and particularly for the evaluation of coastal areas, has been relatively rare. In this situation, an assessment of the attractiveness of European coastal and offshore areas for sailing tourism using the combined AHP and PROMETHEE methodology, seemed to offer some interesting perspectives as the approach integrates these two multi-criteria techniques in order to benefit from their assets and avoid their weaknesses. AHP has been applied to minimise the

\begin{tabular}{|c|c|c|c|c|c|c|c|c|c|c|c|c|}
\hline \multirow{2}{*}{$\begin{array}{l}\text { Criteria } \\
\text { Areas }\end{array}$} & \multicolumn{2}{|c|}{ S\&C } & \multicolumn{2}{|c|}{ NC } & \multicolumn{2}{|c|}{ TA } & \multicolumn{2}{|c|}{$\mathbf{F}$} & \multicolumn{2}{|c|}{ CO } & \multicolumn{2}{|c|}{ A\&L } \\
\hline & 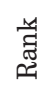 & 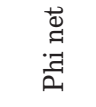 & $\begin{array}{l}\text { ॠี } \\
\text { ॠ్ }\end{array}$ & 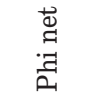 & 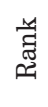 & 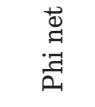 & $\begin{array}{l}\text { त् } \\
\text { జ్ }\end{array}$ & 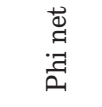 & 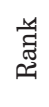 & 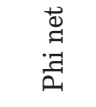 & $\begin{array}{l}\text { त्ञ } \\
\text { స్ }\end{array}$ & 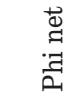 \\
\hline Baltic Sea & 2 & 0.44 & 1 & 0.11 & 3 & -0.22 & 5 & -0.22 & 2 & 0.11 & 1 & 1.00 \\
\hline North Sea & 6 & -0.56 & 1 & 0.11 & 3 & -0.22 & 5 & -0.22 & 2 & 0.11 & 2 & 0.22 \\
\hline Norwegian Sea & 6 & -0.56 & 1 & 0.11 & 3 & -0.22 & 1 & 0.67 & 9 & -0.78 & 2 & 0.22 \\
\hline Irish Sea, Atlantic & 6 & -0.56 & 1 & 0.11 & 3 & -0.22 & 1 & 0.67 & 2 & 0.11 & 2 & 0.22 \\
\hline Eng. Channel, Biscay, Atlantic & 6 & -0.56 & 1 & 0.11 & 3 & -0.22 & 1 & 0.67 & 2 & 0.11 & 2 & 0.22 \\
\hline Atlantic Islands & 2 & 0.44 & 1 & 0.11 & 3 & -0.22 & 5 & -0.22 & 2 & 0.11 & 8 & -0.67 \\
\hline Western Mediterranean & 2 & 0.44 & 1 & 0.11 & 3 & -0.22 & 1 & 0.67 & 2 & 0.11 & 2 & 0.22 \\
\hline Central Mediterranean & 1 & 1.00 & 1 & 0.11 & 1 & 0.89 & 5 & -0.22 & 1 & 1.00 & 2 & 0.22 \\
\hline Eastern Mediterranean & 2 & 0.44 & 1 & 0.11 & 1 & 0.89 & 9 & -0.78 & 2 & 0.11 & 8 & -0.67 \\
\hline Black Sea & 6 & -0.56 & 10 & -1.00 & 3 & -0.22 & 10 & -1.00 & 10 & -1.00 & 10 & -1.00 \\
\hline
\end{tabular}

Tab. 5: Complete rankings of coastal and offshore areas in relation to particular criteria Source: author 


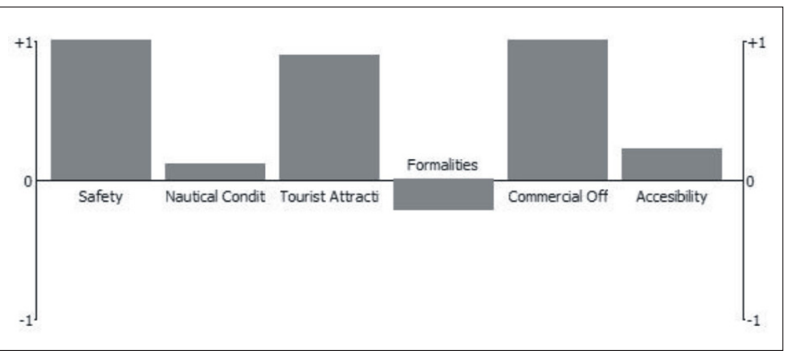

Fig. 6: The assessment of the Central Mediterranean area in terms of particular criteria

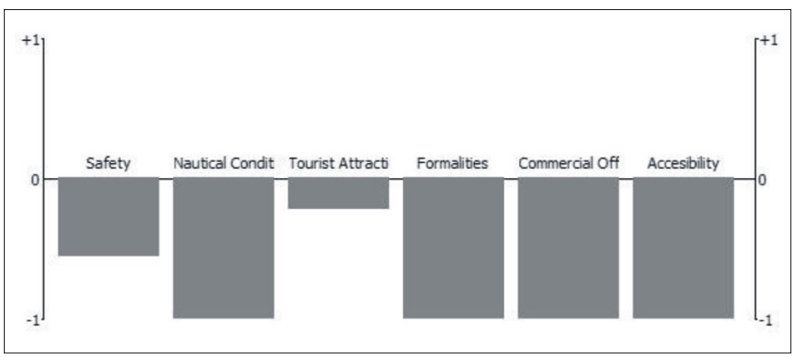

Fig. 7: The assessment of the Black Sea in terms of particular criteria

subjectivity of the researcher at the stage of determination of the weights of the criteria. The PROMETHEE methodology, on the other hand, has been used to conduct the whole evaluation process. The latter has also made it possible to carry out detailed analyses and obtain relevant results, including their graphical presentation.

This research project, likely the first of its type, should contribute to knowledge of the attractiveness of European maritime areas in the context of sailing tourism. Secondly, this approach should also improve the methodological bases of nautical tourism research, including coastal tourism and sailing tourism research. In this context, the current paper focused on two goals. The first concerned the methodological aspects of such research, as the researcher wanted to show, in a detailed way, how both methods in question could be used for the evaluation of given areas (and, by implication, not only for tourism purposes). From this perspective, the empirical research only provided background information, where the proposed combined methodology was tested. The second goal was related to the relative lack of academic knowledge on sailing tourism: to realise this task and increase such knowledge, the author's personal interests and experience in sailing appeared to be an additional asset. The latter factors contributed to the choice of such a subject area as an empirical testing site (not only in the spatial context) for the research. Taking into account these aspects, it is hoped that the paper constitutes a relevant contribution to research on tourism (from both methodological and empirical perspectives).

As in most projects with relatively few antecedents, the limited character of the current work also indicates directions for further investigation. It seems that comparative analyses should be carried out among experts from various European countries, as this could allow the comparison of preferences expressed by different groups of sailors. Additionally, research with a similar methodology could be conducted for at least two other reasons:

1. the assessment of smaller sub-areas (located in a larger geographical territory) in order to determine their competitive positions, e.g. selected coastal areas within the Baltic Sea or the North Sea (this approach could also be applied to other non-European areas); and

2. the evaluation of areas taking into account particular criteria and their weights in relation to various groups of sailors, such as potential visitors (i.e. their assessment in terms of navigation safety, commercial offer, accessibility and location, etc.).

Finally, it is important to emphasise that the results of research of this type can be used for more practical purposes. Such results can not only determine the competitive positions of given (not only maritime) tourism regions, but also point out their relative strengths and weaknesses in relation to particular criteria. This can be particularly interesting and helpful for smaller areas which compete with each other in terms of the various factors. Using knowledge about their (and their competitors') strengths and weaknesses, they could develop specialisations related to their competitive advantages.

Taking into consideration all of the aforementioned advantages of multi-criteria methods, it must be remembered that (despite attempts of their formalisation) they are burdened with a certain degree of subjectivity: experts carry out their assessments in subjective ways; criteria are selected and weighted by them subjectively, etc. Due to this effect, in order to receive a possibly complete and relatively objective picture of a real situation, traditional quantitative analyses are also recommended. Their results should complete more subjective evaluations conducted using multi-criteria methods. In relation to the assessment of European maritime areas, such analyses could concern primarily supply aspects: i.e. factors such as the shoreline development ratio; climate and weather data; locations of destinations (in terms of both time and distance accessibility measures); prices; the number of marinas and yachts, and many other factors.

\section{References:}

ADAMCZYK, T., NOWACKI M. (2014): Ocena atrakcyjności krajoznawczej destynacji żeglarskich z wykorzystaniem metody AHP. Turystyka kulturowa, 8: 51-68.

AKKAYA, G. C., UZAR, C. (2013): The usage of multiplecriteria decision making techniques on profitability and efficiency: an application of PROMETHEE. International journal of economics and finance studies, 5(1): 149-156.

ANHOLT, S. (2010): Places: Identity, image and reputation. Basingstoke, Palgrave Macmillan.

ATLANTIC SPAIN AND PORTUGAL (2006): RCC Pilotage Foundation. Cambridgeshire, Imray.

BALAGUER, P., DIEDRICH, A., SARDÁ, R., FUSTER, M., CAÑELLAS, B., TINTORÉ J. (2011): Spatial analysis of recreational boating as a first key step for marine spatial planning in Mallorca (Balearic Islands, Spain). Ocean \& Coastal Management, 54(3): 241-249.

BARTKOWSKI, T. (1971): O metodyce oceny środowiska geograficznego, Przegląd Geograficzny, 53(3): 263-281.

BLANCAS, J., GUERRERO, F. M., LOZANO, M. (2009): La localización espacial en la planificación del turismo rural en Andalucía: un enfoque multicriterio. Revista de estudios regionals, 84: 83-113.

BRANDON, R., MARCHMENT, J. (2007): Corsica and North Sardinia. Cambridgeshire, Imray. 
BRANDIS, D., MARTÍN, F., CALLE, M., RÍO, M. I., TROITIÑO, M. A., GUTIÉRREZ, J., LOBO, P. (1998): Toledo: problemática e implicaciones urbanas del turismo. Ería, Revista cuatrimestral de geografía. 47: 299-325.

BRANS, J. P., MARESCHAL, B., VINCKE, P.H. (1984): PROMETHEE: a new family of outranking methods in multicriteria analysis. In: Brans, J. P. [ed.]: Operational Research'84 (pp. 477-490), North-Holland.

BRANS, J. P., VINCKE, P. H. (1985): A preference ranking organization method, the PROMETHEE method. Management Science, 31: 647-656.

BUCHANAN, G. (2009): Shetland Islands Pilot. Imray, Cambridgeshire.

BUTOWSKI, L. (2010): Morska turystyka żeglarska w Europie - podstawy metodologiczne analizy jakościowej wybranych elementów popytu i podaży. Folia Turistica, 23: 95-114.

BUTOWSKI, L. (2014): Maritime Tourism Space. Turyzm, 24(1): 57-64.

BUTTRES, R., DU PORT, A. (2009): Reeds Nautical Almanac 2010. Atlantic Europe from the tip of Denmark to Gibraltar. Adlard Coles Nautical.

CABAŁA, P., ONDERKA, Z. (2015): Przegląd metod wielokryterialnego wspomagania decyzji. In: Stabryła, A. [ed.]: Praktyka projektowania systemów organizacyjnych przedsiębiorstwa (pp. 191-199). Kraków, Mfiles.pl.

CHARLIER, R. H., DE MEYER, C. P. (1992): Tourism and the coastal zone: The case of Belgium. Ocean \& Coastal Management, 18(2-4): 231-240.

CHEN, C. F. (2006): Applying the Analytical Hierarchy Process (AHP) Approach to Convention Site Selection. Journal of Travel Research, 45(2): 167-174.

CHO, V. (2008): Linking location attractiveness and tourist intention. Tourism and Hospitality Research, 8(3): $220-224$

CHOU, T. Y., HSU, C. L., CHEN, M. C. (2008): A fuzzy multicriteria decision model for international tourist hotels location selection. International Journal of Hospitality Management, 27(2): 293-301.

COHEN, E. (1972 Spring). Toward a Sociology of International Tourism. Social Research, 39(1): 164-182.

CORNELL, J. (2008): World Crusing Routes. Adlard Coles Nautical, $6^{\text {th }}$ edition.

CRACOLICI, M. F., NIJKAMP, P. (2009): The attractiveness and competitiveness of tourist destinations: A study of Southern Italian regions. Tourism Management, 30: $336-344$

CROUCH, J. (2007): Modelling destination competitiveness: A survey and analysis of the impact of competitiveness attributes. CRC for Sustainable Tourism Pty Ltd., Queensland.

DAGDEVIREN, M. (2008): Decision making in equipment selection: an integrated approach with AHP and PROMETHEE. Journal of Intelligent Manufacturing. 19: $397-406$.

DALTON, T., THOMPSON, R. (2013): Recreational boaters' perceptions of scenic value in Rhode Island coastal waters. Ocean \& Coastal Management, 71: 99-107.
DAVENPORT, J., DAVENPORT, J. (2006): The impact of tourism and personal leisure transport on coastal environments: A review. Estuarine, Coastal and Shelf Science, 67(1-2): 280-292.

DE BRUCKER, K., VERBEKE, A., MACHARIS, C. (2004): The applicability of multicriteria-analysis to the evaluation of intelligent transport systems (ITS). Research in Transportation Economics, 8: 151-179.

DEJA, W. (2001): Przydatność rekreacyjna strefy brzegowej jezior Polski. Poznań, Bogucki Wydawnictwo Naukowe.

DENG, J., KING, B., BAUER, T. (2002): Evaluating natural attraction for Tourism. Annals of Tourism Research, 29(2): 422-438.

DIAKOMIHALIS, M. N., LAGOS, D. G. (2008): Estimation of the economic impacts of yachting in Greece via the tourism satellite account. Tourism Economics, 14(4): 871-887.

DUBEL, K. (2000): Uwarunkowania przyrodnicze w planowaniu przestrzennym. Białystok, Wydawnictwo Ekonomia i Środowisko.

FILIPOWIĆ, M. (2007): The analytic hierarchy process as a support for decision-making. Spatium, 15-16: 44-59.

FORMICA, S., UYSAL, M. (2006): Destination attractiveness based on supply and demand evaluations: An analytical framework. Journal of Travel Research, 44: 418-430.

FRANCO, S., OSORIO, M., NAVA, G., REGIL, H. H. (2009): Evaluación multicriterio de los recursos turísticos. Parque Nacional Nevado de Toluca - México. Estudios y perspectivas en turismo, 18(2): 208-226.

GARTNER, W. (1989). Tourism image: Attribute measurement of state tourism products using multidimensional scaling techniques. Journal of Travel Research, 28(2): 16-20.

GENÇ, A. N. (2015): A Model to Simulate Yacht Movements in Enclosed Bays. Journal of Coastal Research, 31(2): 364-370.

GÖKSU, A., KAYA S.E. (2014): Ranking of tourist destinations with multi-criteria decision making methods in Bosnia and Herzegovina. Economic Review - Journal of Economics and Business, XII(2): 91-103.

GOŁEMBSKI, G. [ed.] (2002): Kompendium wiedzy o turystyce. Warszawa / Poznań, WN PWN.

GOUMANS, M., LYGEROU, V. (2000): An extension of the PROMETHEE method for decision making in fuzzy environment: Ranking of alternative energy exploitation projects. European Journal of Operational Research, 123(3): 606-613.

HALL, C. M. (2001): Trends in ocean and coastal tourism: the end of the last frontier? Ocean \& Coastal Management, 44(9-10): 601-618.

HEATH, N. (2006): The Channel Islands. Cambridgeshire, Imray.

HEIKELL, R. (1998): Mediterranean Cruising Handbook. Cambridgeshire, Imray.

HEIKELL, R. (2006): Italian Waters Pilot. Cambridgeshire, Imray.

HEIKEL, R. (2007): Greek Waters Pilot. Cambridgeshire, Imray. 
HUANG, Y., BIAN, L. (2009): A Bayesian network and analytic hierarchy process based personalized recommendations for tourist attractions over the Internet. Expert Systems with Applications, 36(1): 933-943.

HUSBANDS, W. C. (1983): Tourists space and tourist attraction, an analysis of the destination choices of European travelers. Leisure Sciences, 5(4): 289-307.

HSU, T. K., TSAI, Y. F., WU, H. H. (2009): The preference analysis for tourist choice of destination: A case study of Taiwan. Tourism management, 30(2): 288-297.

IAŢU, C., BULAI, M. (2010): A critical analysis on the evaluation of tourism attractiveness in Romania. Case study: the region of Moldavia. Proceedings of the 5th WSEAS International Conference on Economy and Management Transformation (Volume I, pp. 145-150). Timisoara, West University of Timisoara.

ISHIZAKA, A., NEMERY, P., LIDOUH, K. (2013): Location selection for the construction of a casino in the Greater London region: A triple multi-criteria approach. Tourism Management, 34: 211-220.

JOE, Y. A., KIM, S. (2011): An Application of SWOT - AHP to develop planning for a tourist destination. Texas: Nutrition, Hospitality, and Retailing Department, Texas Tech University, Tourism Education.

KIM, D., PERDUE, R. R. (2011): The influence of image on destination attractiveness. Journal of Travel \& Tourism Marketing, 28: 225-239.

KIM, S. S., AGRUSA, J. (2005): The positioning of overseas honeymoon destinations. Annals of Tourism Research, 32(4): 887-904.

KOVAČIČ, M. (2010): Selecting the location of a nautical tourism port by applying PROMETHEE and GAIA methods. Case study - Croatian Northern Adriatic. Promet - Traffic \& Transportation, 22(5): 341-351.

KOŻUCHOWSKI, K. (2005): Walory przyrodnicze w turystyce i rekreacji. Poznań, Wydawnictwo Kurpisz.

KREŠIĆ， D. (2007): Faktori atraktivnosti turističkih destinacija u funkciji konkurentnosti / Tourism Destination Attractiveness Factors in the Funcion of competitiveness. Acta Turistica, 19(1): 45-82.

KREKRE, D., PREBE, E. D. (2011): Index of destination attractiveness as a tool for destination attractiveness assessment. Tourism, 59(4): 497-517.

KRUCZEK, Z. (2011): Atrakcje turystyczne. Fenomen, typologia, metody badań. Kraków, Proksenia.

LAI, W. H., VINH, N. Q. (2013): An Application of AHP Approach to investigate tourism promotional effectiveness. Tourism and Hospitality Management, 19(1): 1-22.

LAWRENCE, M. (2002): The Yachtsmans Pilot to North and East Scotland. Cambridgeshire, Imray.

LEASK, A. (2010). Progress in visitor attraction research: Towards more effective management. Tourism Management, 31: 155-166.

LEE, H. C. (2001): Determinants of recreational boater expenditures on trips. Tourism Management, 22(6): 659-667.

LEW, A.A. (1987): A Framework of tourist attraction research. Annals of Tourism Research, 14(4): 553-575.
LLORET, J., ZARAGOZA, N., CABALLERO, D., RIERA, V. (2008): Impacts of recreational boating on the marine environment of Cap de Creus (Mediterranean Sea). Ocean \& Coastal Management, 51(11): 749-754.

LUKOVIC, T. (2012): Nautical Tourism and its Functions in the Economic Development in Europe. In: Kasimoglu, M. [ed.]: Visions for Global Tourism Industry - Creating and Sustaining Competitive Strategies (pp. 399-430). Rijeka, In Tech.

LUKOVIC, T. (2013): Nautical Tourism. CABI.

LÜCK, M. [ed.] (2007): Nautical tourism. Concepts and issues. Cognizant Communication Corporation.

LÜCK, M. [ed.] (2008): The Encyclopedia of Tourism and Recreation in Marine Environments, CABI.

MACHARIS, C., VERBEKE, A., DE BRUCKER, K. (2004): The strategic evaluation of new technologies through multicriteria analysis: the Advisors case. Research in Transportation Economics, 8: 443-462.

MARUŠIĆ, Z., HORAK, S., TOMLJENOVIĆ, R. (2008): The socioeconomic impacts of cruise tourism: A case study of Croatian destinations. Tourism in Marine Environments, 5(2): 131-144.

MARROU, L. (2011): Nautical Frequentation and Marina Management. Journal of Coastal Research (Special Issue), 61: 126-132.

MAYO, E. J., JARVIS, L. P. (1981): Psychology of leisure travel. Boston, CABI Publishing.

MIKULIĆ, J., KREŠIĆ, D., KOŽIĆ, I. (2015): Critical factors of the maritime yachting tourism experience: an impact-asymmetry analysis of principal components. Journal of Travel \& Tourism Marketing, 32: 30-41.

MIOSSEC, J. M. (1977: Un modčle de l'espace touristique. L'Espace Géographique. 6(1): 41-48.

MIOSSEC, A. (1988): The physical consequences of touristic development on the coastal zone as exemplified by the Atlantic coast of France between Gironde and Finistčre. Ocean and Shoreline Management, 11(4-5): 303-318.

MONDÉJAR-JIMÉNEZ, J. A., GARCÍA-CENTENO, M. C., MÍNGUEZ-SALIDO, R., MONDÉJAR-JIMÉNEZ, J., CORDENTE-RODRÍGUEZ, M. (2010): Cultural Tourism, Using a Multicriteria Analysis: Spanish World Heritage Cities. International Journal of Management \& Information Systems, 14(4): 35-43.

MONTIS, A., NIJKAMP, P. (2006): Tourism development and collaborative evaluation: a multicriteria web based planning support system. International Journal of Environmental Technology and Management, 6(1-2): 40-64.

MUSZYŃSKA-KURNIK， M. (2010): Atrakcyjność turystyczna Tatrzańskiego Parku Narodowego. Paper published in the IV Conference: The Nature of Tatra National Park and a Man, 3: 69-73.

MOUTINHO, L., RITA, P., CURRY, B. (1996): Expert Systems in Tourism Marketing. London, Routledge.

NAVIN, B. (2004): Cruising Guide to the Netherlands. Cambridgeshire, Imray.

NAVIN, B. (2006): Cruising Guide to Germany and Denmark. Cambridgeshire, Imray.

NAVIN, B. (2003): North Sea Passage Pilot. Cambridgeshire, Imray. 
NICKEL, P., HARRIES J. (2009): Norwegian Cruising Guide 2009, Norway, Swalbard, and the West Coast of Sweden. Hamilton, Bermuda, Atteinable Adventure Cruising Ltd.

NEKOOEE, Z., KARAMI, M., FAKHARI, I. (2011): Assessment and Prioritization of Urban Tourist Attractions Based on Analytical Hierarchy Process (AHP): A Case Study of Birjand, Iran. Iran Journal of Applied Business and Economics, 12(4): 122-134.

OCEAN PASSAGES FOR THE WORLD (2004): NP 136, Fifth Edition, United Kingdom Hydrographic Office.

OMERZEL GOMZELJ, D., MIHALI, T. (2008): Destination competitiveness-Applying different models, the case of Slovenia. Tourism Management, 29(2): 294-307.

ORAMS, M. B. (2007): The impact of hosting a major marine sports tourism event: The America's cup in Auckland, New Zealand. In: Luck, M. [ed.]: Nautical tourism: Concept and issues (pp. 97-105). New York, Cognizant Communication Corporation.

OTAMENDI，F. J., GONZÁLEZ DE VEGA J. R. (2014): Recreational boating incidents based on marine surveyors reports: Economic, safety and prevention issues across Spain. Ocean \& Coastal Management, Vol. 102, Part A: 65-71.

PAPATHANASSIS, A., ROSS, A. K. [eds.] (2015): Tourism in Marine Environments. Special issue Cruise Tourism. Cognizant Communication Corporation.

PAPIĆ-BLAGOJEVIĆ, N., GAJIĆ, T., DJOKIĆ, N. (2012): Using Bayesian network and AHP method as a marketing approach tools in defining tourists' preferences. Turizam, 16(1): 8-19.

PAPRZYCKA, A. (2005): Kryteria typologii i oceny krajobrazu kulturowego. In: Szponar, A., Horska-Schwarz, S. [eds.]: Struktura funkcjonalno-przestrzenna krajobrazu (pp. 78-83). Wrocław, Uniwersytet Wrocławski.

PARRAIN, C. (2011): Sailing Routes and Stopovers: Spatial Disparities Across the Atlantic. In: Micallef, A. [ed.]: Journal of Coastal Research (Special Issue), 61: $140-149$.

PÉREZ, V., CAMARGO, I., CABALLERO, R., GONZÁLEZ, M. (2008): Selección multicriterio de nuevos productos turísticos en Pinar del Río, Cuba. Revista Investigación Operacional, 2(2): 98-107.

PIKKEMAAT, B. (2004). The measurement of destination image: The Case of Austria. The Poznan University of Economics Review, 4(1): 87-102.

PROMETHEE methods. Visual PROMETHEE 1.4 Manual, 2014. VP Solutions [online] [cit. 01.05.2016]. Available at: http://www.promethee-gaia.net/software.html

QANIR, A. (1989): Planning of marina developments along the Moroccan coastline. Ocean and Shoreline Management, 12(5-6): 561-570.

RAYMOND, C.M., BROWN, G. (2006): A method for assessing protected area allocations using typology of landscapes values. Journal Environmental Planning Management, 49(6): 797-812.

RANJAN, R., CHATTERJEE, P., CHAKRABORTY, S. (2016): Performance evaluation of Indian states in tourism using an integrated PROMETHEE-GAIA approach. Opsearch, 53(1): 63-84.
RETIERE, D. (2002): Pratiques plaisancičres: évolution et spatialisation dans le Soient (Grande- Bretagne) et la baie de Quiberon (France). In: Guillaume, P. [ed.]: Les activités littorals (pp. 147-168). Paris, CTHS.

RITCHIE, B. J., CROUCH, G. I. (2005): The Competitive Destination: A Sustainable Tourism Perspective. Wallingford, CABI Publishing.

ROGALEWSKI, O. (1974): Zagospodarowanie turystyczne. Warszawa, WSiP.

ROZMAN, C., POTOCNIK, M., PAZEK, K., BOREC, A., MAJKOVIC, D., BOHANEC, M. (2009): A multi-criteria assessment of tourist farm service quality. Tourism Management, 30(5): 629-637.

SAATY, T. L. (1980): The analytic hierarchy process. New York, McGraw.

SAATY, T. L. (1982): Decision making for leaders. Lifetime learning publications. Belmont, Wadsworth.

SAATY, T. L. (1987): The analytic hierarchy process - what it is and how it is used. Mathematical Modelling, 9(35): $161-176$

SAATY, T. L. (1995): Decision making for leaders. The analytical hierarchy process for decisions in a complex world. Pittsburgh, RWS publications.

SAATY, T. L. (2008): Decision making with the analytic hierarchy process. International Journal of Services Sciences, 1(1): 83-98.

SALMONA, P., VERARDI, D. (2001): The marine protected area of Portofino, Italy: A difficult balance. Ocean \& Coastal Management, 44: 39-60.

SILVEIRA, L., SANTOS, N. (2012): The marina of Horta (Azores Island) - Impacts on the local population and in the tourism development. Proceeding of the $7^{\text {th }}$ International Coastal \& Marine Tourism Congress (pp. 117-129). Breda, NHTV Breda University of Applied Science.

SILVEIRA, L., SANTOS, N. (2013): Marina Impacts on the Local Population and on Tourism Development in Horta (Azores Islands), Portugal. Tourism in Marine Environments, 9(1-2): 193-202.

SOŁOWIEJ, D. (1992): Podstawy metodyki oceny środowiska przyrodniczego człowieka. Poznań, Wyd. Nauk. UAM.

SOUTH AND WEST COASTS OF IRELAND (2006): Sailing Directions of Irish Cruising Club.

THOMPSON, T., THOMPSON, D. (2008): Adriatic Pilot. Cambridgeshire, Imray.

TURCKSIN, L., BERNARDINI, A., MACHARIS, C. (2011): A combined AHP-PROMETHEE approach for selecting the most appropriate policy scenario to stimulate a clean vehicle fleet. Procedia Social and Behavioral Sciences, 20: 954-965.

UYGURTÜRK, H., KORKMAZ, T. (2015): The Determination of Preference Ranking of a Group Travel Agencies in Turkey with PROMETHEE Method. Business and Economics Research Journal, 6(2): 141-155.

WANG, J. J., YANG, D. L. (2007): Using a hybrid multicriteria decision aid method for information systems outsourcing. Computers and Operation Research, 34: 3691-3700.

WORM, K. (1997): Coastal zone planning in Denmark. Ocean \& Coastal Management, 37(2): 253-268. 
YOON, Y., UYSAL, M. (2005): An examination of the effects of motivation and satisfaction on destination loyalty: a structural model. Tourism Management, 26(1): 45-56.

ZAJADACZ, A., ŚMIAŁEK, J. 2009): Ocena potencjału turystycznego. In: Młynarczyk, Z., Zajadacz, A. [eds.]: Tourist development: determinants and plans. Volume 3 - The tourist values and attractions. Touristic potential. Plans of the development of tourism (pp. 3561). Poznań, Adam Mickiewicz University Press.

ZHOU, Y., MAUMBE, K., DENG, J., SELIN, S. W. (2015): Resource-based destination competitiveness evaluation using a hybrid analytic hierarchy process (AHP): The case study of West Virginia. Tourism Management Perspectives, 15: 72-80.
ZIOŁKOWSKI, R. (2006): Praktyczne aspekty rozwoju turystyki i rekreacji na obszarach przyrodniczo cennych. Białystok, Wydawnictwo Politechniki Białostockiej.

ŻEMŁA， M. (2014): Autentyczność obiektywistyczna wybranych typów atrakcji w oczach turysty w kształtowaniu doświadczenia turystów. Zeszyty Naukowe Uniwersytetu Szczecińskiego, 1(25): 385-404.

\section{Please cite this article as:}

BUTOWSKI, L. (2018): An integrated AHP and PROMETHEE approach to the evaluation of the attractiveness of European maritime areas for sailing tourism. Moravian Geographical Reports, 26(2): 135-148. Doi: 10.2478/mgr-2018-0011. 